\title{
Author Correction: High-Sensitivity cardiac Troponins in Cardio- Healthy Subjects: A Cardiovascular Magnetic Resonance Imaging Study
}

\section{Tar-Choon Aw $\mathbb{1}^{1}$, Wei-ting Huang ${ }^{2}$, Thu-Thao Le ${ }^{2}$, Chee-Jian Pua ${ }^{2}$, Briana Ang ${ }^{2}$, Soon-} Kieng Phua ${ }^{1}$, Khung-KeongYeo $\mathbb{D}^{2}$, Stuart A. Cook ${ }^{2,3}$ \& Calvin W. L. Chin ${ }^{2,3}$

Correction to: Scientific Reports https://doi.org/10.1038/s41598-018-33850-9, published online 18 October 2018

The original version of this Article contained errors in the title of the paper, where "High-Sensitivity cardiac Troponins in" was incorrectly given as "High-Sensitivitycardiac Troponinsin". This has now been corrected in the PDF and HTML versions of the Article.

(i) Open Access This article is licensed under a Creative Commons Attribution 4.0 International cc) License, which permits use, sharing, adaptation, distribution and reproduction in any medium or format, as long as you give appropriate credit to the original author(s) and the source, provide a link to the Creative Commons license, and indicate if changes were made. The images or other third party material in this article are included in the article's Creative Commons license, unless indicated otherwise in a credit line to the material. If material is not included in the article's Creative Commons license and your intended use is not permitted by statutory regulation or exceeds the permitted use, you will need to obtain permission directly from the copyright holder. To view a copy of this license, visit http://creativecommons.org/licenses/by/4.0/.

(C) The Author(s) 2019

${ }^{1}$ Department of Laboratory Medicine, Changi General Hospital, 2 Simei Street 3, Singapore, 529889, Singapore. ${ }^{2}$ Department of Cardiology, National Heart Center Singapore, 5 Hospital Drive, Singapore, 169609, Singapore. ${ }^{3}$ Duke-NUS Medical School, Singapore, Singapore. Tar-Choon Aw and Wei-ting Huang contributed equally. Correspondence and requests for materials should be addressed to T.-C.A. (email: tarchoon@gmail.com) 